\title{
Investigating Teachers' Attitudes towards Teaching and Learning of English as a Lingua Franca (ELF) in Indonesian EFL Context
}

\author{
Siffa Annisa Firi Ramadhani \& Ahmad Bukhori Muslim \\ Universitas Pendidikan Indonesia, Bandung, Jawa Barat, Indonesia \\ siffaafr@upi.edu, abukhmuslim@upi.edu
}

Naskah diterima tanggal 23/07/2021, direvisi akhir tanggal 29/07/2021, disetujui tanggal 14/08/2021

\begin{abstract}
Abstrak
Bahasa Inggris sebagai Lingua Franca (English as a lingua franca-ELF) telah mendapatkan perhatian yang tinggi dalam pengajaran bahasa Inggris tetapi masih kurang diteliti dalam konteks Bahasa Inggris sebagai Bahasa Asing (English as a foreign language-EFL) seperti di Indonesia. Penelitian ini bertujuan untuk meneliti sikap guru terhadap ELF dan beberapa kemungkinan tantangan dalam memasukkan pengajaran ELF ke dalam praktik pengajaran mereka. Menggunakan metode deskriptif kuantitatif dengan memberikan survei cross-sectional kepada 50 guru EFL di Jakarta, penelitian ini telah menemukan bahwa para guru memiliki sikap positif terhadap penggunaan ELF dalam proses belajar mengajara di konteks EFL Indonesia. Namun, ditemukan juga tidak familiernya guru dengan aksen lain, kesiapan guru, siswa, dan institusi dalam memasukkan pengajaran ELF, menyediakan materi pembelajaran yang sesuai, dan penutur asli sebagai tantangan yang dihadapi dalam memasukkan ELF ke dalam pengajaran mereka. Studi ini menawarkan beberapa saran untuk menjelaskan perkembangan guru dan peningkatan pengajaran ELF dalam konteks Indonesia.

Kata kunci: Sikap Guru EFL, Bahasa Inggris sebagai Lingua Franca (EFL), konteks EFL Bahasa Indonesia.
\end{abstract}

\begin{abstract}
English as a Lingua Franca (ELF) has received increased attention in English teaching but is still less studied in an EFL context like Indonesia. This study aims at investigating teachers' attitudes toward ELF and some possible challenges in incorporating ELF instruction into their teaching practices. Employing a quantitative descriptive method by administering a cross-sectional survey to 50 EFL teachers in Jakarta, the study revealed that the teachers had a positive attitude towards teaching and learning ELF in the Indonesian EFL context. However, it is also discovered teachers accentuated unfamiliarity with other accents, the readiness of teachers, students, and institutions in incorporating ELF instruction, providing suitable learning materials, and native speakers as challenges encountered in incorporating ELF into their teaching. This study offered several suggestions to shed a light upon teachers' development and enhancement of teaching ELF in the Indonesian context.
\end{abstract}

Keywords: EFL Teachers’ attitudes, English as a Lingua Franca (EFL), Indonesian EFL context.

How to cite (APA Style): Ramadhani, S. A. F. \& Muslim, A. B. (2021). Investigating teachers' attitudes towards teaching and learning of English as a lingua franca (ELF) in Indonesian EFL Context. Jurnal Penelitian Pendidikan, 21(2), 2021, 66-79. doi: https://doi.org/ 10.17509/jpp.v21i2.35131

\section{INTRODUCTION}

The global spread of English has caused the number of English speakers to grow impressively. The speakers of English have reached a third of the world's population and they will keep growing to more than 450 million in the following 50 years (Coskun, 2010; Crystal, 2003). With the number of its speakers, English undeniably has become an international language which is spoken by the majority of people across the world with covering different purposes such as economic purposes, educational purposes, and entertainment purposes which all refer to communication (Crystal, 2003; Kaur, 2010; Mairi, 2016). Consequently, it is clear that there is a change in the status of English. English currently has functioned as English as a Lingua Franca (ELF) which facilitates communication among people with different lingua-cultures all over the globe (Fang, 2017). 
Generally, the term of English as a Lingua Franca (ELF) refers to the use of English as a common language of choice among speakers who have a different linguacultural background (Jenkins, 2009; Kaur, 2010). It is also defined as the contact language of people who do not share a common language or culture and for whom English is the communication language (Firth, 1996). In line with this, ELF functions as a bridge in communication between people beyond linguacultural boundaries covering native speakers of English and nonnative speakers of English (Seidlhofer, 2005; 2011). It means that ELF communication is not only based on a specific community, such as expanding circle countries, yet it covers all interactions in Kachru's three circles (Bjørge, 2012; Mauranen, 2018; Seidlhofer, 2009). In short, ELF is the use of English as a favored language by the majority of people whose diverse linguistic and cultural backgrounds as a medium of communication.

The concept of ELF emphasizes the real sociolinguistic necessity to achieve effective communication in multilingual settings rather than merely imitating native speakers (Kirkpatrick \& Sussex, 2012). It is indicated that the ELF perspective does not perceive the native model as the target language in learning English. In line with this, ELF is considered a concept that embraces all varieties of English spoken by both native and nonnative English speakers (Jenkins, Cogo, \& Dewey, 2011). Further, ELF is a concept that encourages language learners with multilingual ideas to communicate with each other and it focuses on the importance of being able to communicate in various situations (Kirkpatrick \& Sussex, 2012).

Concerning the change of English status as a lingua franca, many scholars (e.g., Brown, 2012; Floris, 2014; Luo, 2016; Matsuda, 2003; Matsuda \& Friedrich, 2011; McKay, 2003; 2012; Yücedağ \& Karakaş, 2019) have argued to reconsider the teaching of English as a foreign language which has been oriented to traditional approaches where native speakerism is highly emphasized. It is argued that revisiting and reframing ELT practice is required to adequately prepare learners to effectively interact and communicate with English speakers from different English-speaking contexts (Matsuda \& Friedrich, 2011). Thus, it has become essential to design English curricula and instruction which can prepare learners to deal with international communication where English variations are evident (Luo, 2016).

Teaching English in Indonesia has been oriented to native speakerism (Mukminatien, 2012). It means that the target model of learning English is native speakers and it focuses on achieving nativelike competences. This fact seems to be a salient characteristic of teaching English in expanding circle countries including Indonesia (Evans, 2010; Kang, 2015; Monfared \& Khatib, 2018; Saengboon, 2015; Snodin \& Young, 2015). Given the fact that English has become a lingua franca, initiatives need to be taken to modify the practice of teaching English in Indonesia (Musthafa, Hamied, \& Zein, 2019) so that teaching English in Indonesia can be enhanced and be coped with ELF era. One of the essential factors in coping with the ELF era is teachers' critical attitudes as disregarding their attitudes can lead to failure to apply any educational policies (Asakereh, Yousofi, \& Weisi, 2019; Bayyurt \& Sifakis, 2015). Thus, it is important to see teachers' attitudes towards the phenomenon of ELF which can possibly affect their teaching practices.

Previous studies regarding teachers' views of ELF have been carried out by scholars. Kaur (2014) investigated the attitude of trainee teachers toward accents of ELF. The study revealed that the teachers positively viewed native speaker accents as a more correct and appropriate accent than nonnative speaker accents. Similarly, Rahayu (2019) found that EFL teachers in Indonesia favored British and American accents and perceived Standard English as the most suitable for English language teaching. In the context of teaching practice, Decke-Cornill (2002) conducted a study of German teachers' attitudes to ELF. The finding revealed that the teachers preferred to teach 'proper' English rather than ELF features. This finding indicated that German teachers had a strong emphasis on native speakerism. 
In line with this, Soruç's (2015) study showed that non-native teachers in Turkey had a strong tendency for ENL norms in their teaching practices. In contrast, İnceçay and Akyel (2014) reported that most teachers were tolerant to students who used features similar to ELF yet they portrayed resistance to the use of ELF in their classes.

According to the aforementioned studies, it is apparent that most teachers were oriented to native speakerism and they seemed to be hesitant to incorporate ELF into their teaching practices. Given that fact, this study intends to fill the research gap by focusing on investigating teachers' attitudes toward ELF and the possible challenges of incorporating ELF instruction into their teaching practices. Therefore, this study attempts to figure out two research questions below:

1. What are EFL teachers' attitudes toward teaching and learning English as a Lingua Franca in the Indonesian EFL context?

2. What are possible challenges that might be encountered by teachers when they incorporate ELF instruction into their teaching?

\section{RESEARCH METHOD}

A descriptive quantitative approach was employed in order to answer the research questions of this study. In line with this, a cross-sectional survey was delivered to 50 EFL teachers in Jakarta. The survey was adopted from a questionnaire made by Luo (2016) which consisted of 32 questions. The questions were classified into 2 parts, which are, demographic information and attitudes toward teaching English as a Lingua Franca (ELF). The attitudes toward teaching English as a Lingua Franca (ELF) part covered awareness and legitimacy of ELF, attitude towards native and non-native users of English in the context of EFL in Indonesia, perceptions of teaching objectives in English language teaching, the goals of learning English as a foreign language and perceptions of incorporating ELF into teaching. Those questions were presented in Likert-scale and open-ended questions. The questionnaire was administered online through Google Form on the 10th - 26th of February 2021. In relation to research ethics, consent was also delivered to the participants. Last, the questionnaire was analyzed by using descriptive quantitative to figure out the percentage of each item.

The first section of the questionnaire aimed at obtaining demographic information of the participants. The section covered questions of gender, education level, teaching experience, school level, and first language. Therefore, the findings of the participants' demographic information are presented in Table 1.

Table 1. Demographic Information

\begin{tabular}{llrc}
\hline & Category & f & $\begin{array}{c}\text { Percentage } \\
(\boldsymbol{\%})\end{array}$ \\
\hline Gender & Male & 13 & 26 \\
& Female & 37 & 74 \\
Level of Education & Master Degree & 23 & 46 \\
Teaching Experience & Bachelor Degree & 27 & 54 \\
& Less than 1 year & 1 & 2 \\
& $1-4$ year & 37 & 74 \\
Level & 5-9 year & 7 & 14 \\
& More than 9 year & 5 & 10 \\
& Primary & 8 & 16 \\
& Secondary & 10 & 20
\end{tabular}




\begin{tabular}{llrr} 
& Upper secondary & 15 & 30 \\
& University & 9 & 18 \\
Other & 8 & 16 \\
First language & Bahasa Indonesia & 37 & 74 \\
& Local languages & 13 & 26 \\
\hline
\end{tabular}

First of all, the total number of the participants was 50 teachers of which $74 \%$ were females and $26 \%$ of the students were males. They had different levels of education and teaching experience. The findings revealed that the education level of the participants was $54 \%$ bachelor degree and $46 \%$ master degree. Additionally, more than half the participants have been teaching English for 1-4 years. 14\% of the participants have been teaching English for 5-9 years. Further, the finding also showed that $10 \%$ of the participants had experience teaching English for more than 9 years. In line with this, the school levels were also diverse. Most of the participants taught English at the upper secondary level (30\%), $18 \%$ of them taught in university and less than $25 \%$ of them taught in primary and secondary levels. The finding also depicted some teachers have been teaching in multiple levels of schools such as in upper secondary and university level (16\%). Finally, the last question focused on the first language of the participants. More than half of the total number of the participants spoke Bahasa Indonesia as their first language. Meanwhile, $26 \%$ of the participants mentioned their local languages such as Javanese and Sundanese.

\section{RESULT AND DISCUSSION}

\section{Results}

\section{Teachers' attitudes towards ELF in Indonesian EFL context}

The second section of the questionnaire aimed at investigating EFL teachers' attitudes toward teaching and learning ELF in the Indonesian EFL context. There were 18 questions designed to figure out teachers' attitudes in covering awareness and legitimacy of ELF, attitude toward native and nonnative speakers of English, perceptions of teaching objectives in English language teaching, and the goals of learning English as a Foreign Language.

\section{Awareness and legitimacy of ELF}

As can be seen in Table 2, the findings revealed that most of the participants agreed with the statements regarding awareness and legitimacy of ELF. All the participants agreed that English is used by people from different first languages and cultures globally.

Table 2. Awareness and legitimacy of ELF respond

\begin{tabular}{|c|c|c|c|}
\hline \multirow[t]{2}{*}{ No } & \multirow[t]{2}{*}{ Statements } & \multicolumn{2}{|c|}{ Respond } \\
\hline & & \multicolumn{2}{|c|}{$\%$} \\
\hline 9 & $\begin{array}{l}\text { Teaching English should prepare learners to communicate well inside } \\
\text { and outside the classroom rather than focusing on grammar correctness } \\
\text { only }\end{array}$ & 96 & 4 \\
\hline 10 & $\begin{array}{l}\text { Nowadays, English is spoken by people who have different first } \\
\text { languages and cultures across the world }\end{array}$ & 100 & \\
\hline 11 & $\begin{array}{l}\text { How familiar are you with the notion of English as a lingua franca } \\
\text { (ELF) and its meaning? }\end{array}$ & & \\
\hline & $\begin{array}{l}\text { a. I am familiar with the notion of English as a lingua Franca and I } \\
\text { can clearly describe its meaning. }\end{array}$ & 56 & \\
\hline & b. I have heard about English as a lingua franca but I am not sure & 40 & \\
\hline
\end{tabular}




\begin{tabular}{llr}
\hline \multicolumn{2}{c}{ about the meaning. } \\
12 c. I have no heard about English as a lingua franca. \\
$\begin{array}{l}\text { English teachers should aware of students' local varieties and try to } \\
\text { bring them into the classroom. }\end{array}$ & 92 & 8 \\
13 & $\begin{array}{l}\text { English teachers should accommodate students' L1 when teaching } \\
\text { English } \\
\text { Do you think statements number } 12 \text { and } 13 \text { should be considered in the } \\
\text { curriculum / suitable for learners? }\end{array}$ & 80 \\
\hline
\end{tabular}

This finding indicates that the teachers were aware of the function of English as a lingua franca. In line with this, more than $50 \%$ of the participants were familiar with the notion of ELF and clearly explain the meaning. Moreover, the participants positively accepted that English teachers should be aware of students' local varieties and try to bring them into the classroom (item 15) and should accommodate students' L1 when teaching English (item 16) to be considered in the curriculum. In short, the participants were aware of ELF and its legitimacy in the EFL classroom.

\section{Attitude towards native and non-native users of English in the context of EFL in Indonesia}

The findings in Table 3 showed that the participants mostly did not focus on native-speaker norms in teaching English (15 and 19) and they viewed that nonnative speakers of English also contributed to the development of the English language (20 and 21).

Table 3. Attitude toward native and non-native users of English in the context of EFL

\begin{tabular}{|c|c|c|c|}
\hline \multirow[t]{2}{*}{ No } & \multirow[t]{2}{*}{ Question } & \multicolumn{2}{|c|}{ Respond } \\
\hline & & Yes & No \\
\hline 15 & English teaching should rely on native-speaker norms of English & 48 & 52 \\
\hline 16 & $\begin{array}{l}\text { Teachers should adjust to learners' ability as nonnative speakers of } \\
\text { English }\end{array}$ & 92 & 8 \\
\hline 17 & $\begin{array}{l}\text { The incorporation of L1 sources in teaching English is beneficial } \\
\text { for learners }\end{array}$ & 84 & 16 \\
\hline 18 & $\begin{array}{l}\text { The use of multilingual resources in ELF interaction may enhance } \\
\text { the effectiveness of communication }\end{array}$ & 96 & 4 \\
\hline 19 & $\begin{array}{l}\text { Real, authentic English is spoken only by its native speakers who } \\
\text { consider it their first language }\end{array}$ & 46 & 54 \\
\hline 20 & $\begin{array}{l}\text { The development of the English language can be influenced only by } \\
\text { its native speakers }\end{array}$ & 24 & 76 \\
\hline 21 & $\begin{array}{l}\text { Non-native speakers of English have an important role in the } \\
\text { development of the English language }\end{array}$ & 96 & 4 \\
\hline 22 & $\begin{array}{l}\text { Should teach English value students' linguistic resources (the use of } \\
\text { L1, accent, or variety) as a means of preparing learners for the real } \\
\text { situation? }\end{array}$ & 94 & 6 \\
\hline
\end{tabular}

Furthermore, they rather put more emphasis on adjusting their students' ability as nonnative speakers of English in teaching practice (16). Additionally, the participants focused on the effectiveness of communication by using multilingual resources and incorporating L1 into ELF practice to prepare learners involving in realistic situations $(17,18,22)$. To conclude, the participants possessed a positive attitude to native and non-native users of English in the context of EFL in Indonesia.

\section{Perceptions of teaching objectives in English language teaching}


In regard to teaching objectives, there were some contradictories revealed in this present study. First of all, most of the participants accentuated standard norms of English in terms of teaching objectives and assessment (see Table 4). The participants claimed that EFL learners should be oriented to standard norms of English (24). It is indicated that the participants referred to native speakerism. In line with this, most of the participants believed that competence of English should be defined in reference to Standard English (25). In the same way, the participants agreed that EFL learners should be evaluated based on the standard norm of English (26). In opposite, even though most of the participants intensified the standard norm of English, they did not agree to teach only one specific variety of English, such as British English or American English (24). This statement is in line with teachers' positive attitude toward awareness of ELF and its legitimacy in the EFL context mentioned in part a. Furthermore, more than $80 \%$ of the participants claimed that focusing on communicative effectiveness was much more essential than focusing on formal correctness in regard to evaluating the students (27).

Table 4. Perceptions of teaching objectives in English language teaching

\begin{tabular}{|c|c|c|c|}
\hline \multirow[t]{2}{*}{ No } & \multirow[t]{2}{*}{ Question } & \multicolumn{2}{|c|}{ Respond } \\
\hline & & Yes & No \\
\hline 23 & EFL learners should be oriented to standard norms of English & 68 & 32 \\
\hline 24 & $\begin{array}{l}\text { EFL learners should be taught only a native standard form of } \\
\text { English, such as Standard British English or Standard American } \\
\text { English }\end{array}$ & 38 & 62 \\
\hline 25 & $\begin{array}{l}\text { Competence in English should be defined in reference to Standard } \\
\text { English }\end{array}$ & 70 & 30 \\
\hline 26 & $\begin{array}{l}\text { EFL learners should be evaluated based on standard norms of } \\
\text { English }\end{array}$ & 58 & 42 \\
\hline 27 & $\begin{array}{l}\text { When evaluating students, it is more important to focus on } \\
\text { communicative effectiveness rather than formal correctness }\end{array}$ & 84 & 36 \\
\hline
\end{tabular}

This fact was contradictory with the standard norm of English preferred by the participants since the standard norm of English focuses on native speakerism and formal correctness. In conclusion, the participants believed that standard norms of English were a necessity in teaching objectives yet they realized that communicative effectiveness was prominently important rather than formal correctness.

\section{The goals of learning English as a Foreign Language}

In Figure 1, The finding portrayed that almost all participants believed that the ultimate goal of learning EFL is to help students become efficient communicators in international and multilingual communication $(98 \%)$. 


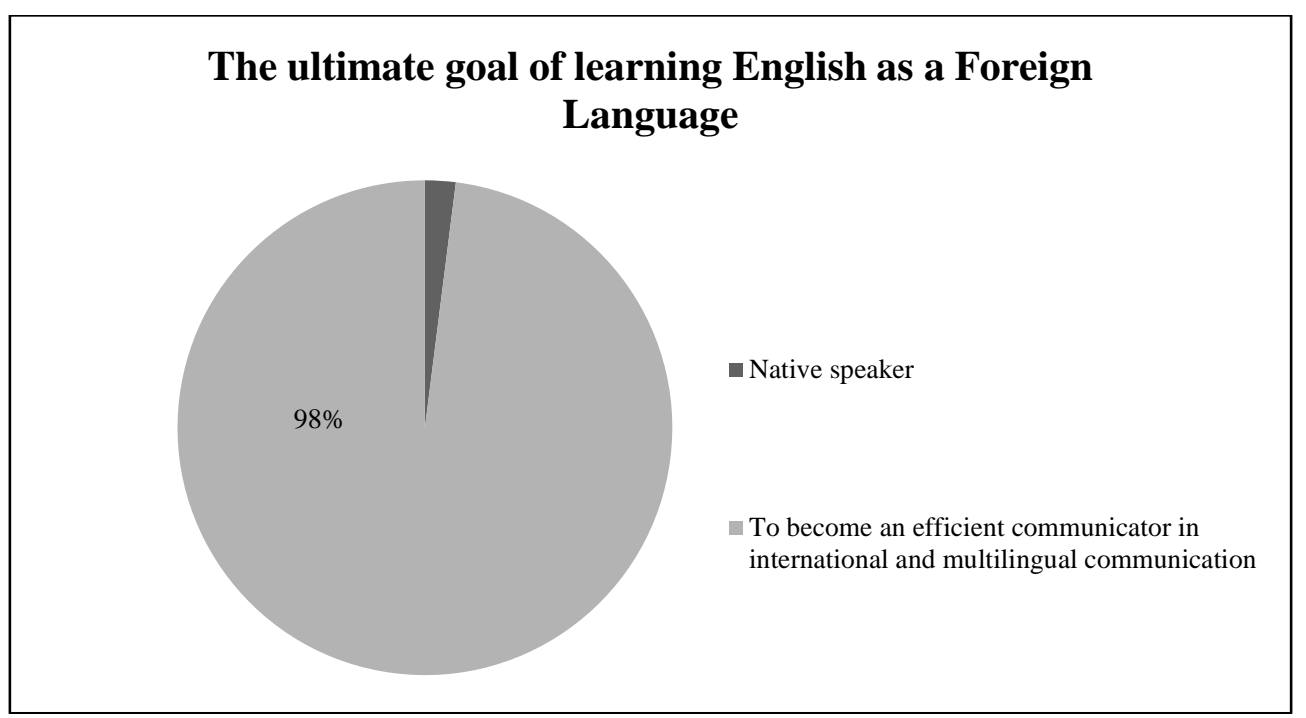

Figure 1. The Ultimate Goal of Learning English as a Foreign Language

This finding indicated that the participants realized that achieving native-like competences did not relate to the reality of how English has been used across the globe nowadays. Hence, the participants perceived the ultimate goal of learning EFL was helping students to be efficient communicators in international and multilingual communication beyond language diversity and cultures.

\section{Perceptions of incorporating ELF into teaching}

The two items presented in Table 5 regarding the perceptions of incorporating ELF into teaching presented a similar percentage.

Table 5. Perceptions of incorporating ELF into teaching

\begin{tabular}{llcc}
\hline No & \multicolumn{1}{c}{ Question } & \multicolumn{2}{c}{ Respond } \\
& Yes & No \\
\hline 29 & $\begin{array}{l}\text { Do you believe that EFL learners should be aware of different } \\
\text { varieties of English and learn them in the classroom? } \\
\text { Do you believe that being aware of ELF and learning about it is } \\
\text { necessary for foreign language learners of English? }\end{array}$ & 90 & \multirow{2}{*}{10} \\
\hline
\end{tabular}

More than $90 \%$ of the participants agreed that ELF awareness was a necessity for the learner. The participants also highly accepted the incorporation of ELF into the classroom. In short, the participants positively perceived the incorporation of ELF into their teaching practice.

\section{Some challenges in incorporating ELF into English teaching}

This present study revealed some challenges accentuated by the participants concerning incorporating ELF instruction into the classroom. The challenges covered unfamiliarity with other accents, the readiness of students, teachers, and institutions, providing materials, and native speakerism. The explanations of the challenges are explained in the following sections. 
Firstly, the findings showed that the participants agreed that unfamiliarity with other accents was a major possible problem. They added teaching British English and American English was a daunting task, so teaching other accents can trouble them. As mentioned by a participant,

"The students are not familiar with other accents and they do not understand British and American English. So it is quite challenging to teaching other accents..." (Participant 1)

Another participant also highlighted that unfamiliarity with other accents can make students confused since they are not well-acquainted with the accents.

"Students will be unfamiliar with those accents spoken by different cultural groups of people. As a result, they are not quite understandable for students. They also need more time to grasp the idea of ELF and understand those differences." (Participant 26)

Secondly, the participants mentioned that there was a need for the readiness of teachers, students, and institutions when they attempt to incorporate ELF instruction in the classroom. As claimed by a participant,

"I think, as a teacher, we have to make sure that we understand the concept of ELF. Moreover, we also need to know whether it is appropriate for the students and teaching objectives." (Participant 6)

The following statement indicated that teachers' readiness of ELF is important before attempting to introduce students to ELF.

"I think the first challenge is how teachers direct the students and make sure that the students have good understanding about English. In my case, my students' understanding of basic context, such as using 'to be' is still limited. They cannot even use it correctly, or simply pronounce 1 English word well."

Another participant highlighted that incorporating ELF in the classroom might be possible for a certain level of education yet considerations were prominently essential.

"In my case, as I taught elementary students, different standards of English might confuse them. It is such a dilemma to introduce many kinds of English since they just learn the language..." (Participant 13).

Additionally, providing suitable materials was also mentioned by the participants as a prospective challenge.

"Providing materials which include people who speak English with different first language is going to be hard. Maybe I can still find them but I am not sure if they are adequate. To be honest, it is clearly easier to get materials which contain native speaker norms..." (Participant 9)

Another challenge mentioned by participants was native speakerism. The participants argued that students actually expected to speak like native speakers because of its prestige and legitimacy. This fact was portrayed in the following statements expressed by the participants.

"To make the learners understand that English does not belong to certain countries but as the union language in the international community, and maybe to make the learners understand the concept of ELF will be the possible challenge as well."

"Some students or parents might still think that the ultimate goal of learning English is to be able to speak exactly like NS, either British or American."

"The Standard English and native English speakers are still the standard and school and they are still desirable. When students are asked about their learning goals, they still want to achieve native- 
like pronunciation and fluency. Besides, being introduced to varieties of English is nice but it is not yet their goal."

\section{Discussion}

\section{Teachers' attitudes towards ELF in Indonesian EFL context}

This present study revealed that the EFL teachers involved in this study had positive attitudes toward teaching and learning English as a lingua franca in the Indonesian EFL context. The teachers were aware of ELF and its legitimacy in the EFL classroom. They also expressed positively about native and non-native users of English in the context of EFL in Indonesia. In addition, they believed that standard norms of English were a necessity in teaching objectives yet they realized that communicative effectiveness was prominently important rather than formal correctness. In the same way, they perceived the ultimate goal of learning EFL was not becoming native-like English users yet becoming efficient communicators in international and multilingual communication beyond language diversity and cultures. Furthermore, they positively assimilated the incorporation of ELF into their teaching practice. Therefore, the aforementioned findings are presented in the following discussion.

The present study depicted an interesting finding. The finding revealed that the teachers were aware of ELF and its legitimacy in the EFL classroom. The teachers accepted the reality of English in today's globalized world and the importance of how teaching English should accommodate students' L1 and local varieties. This finding was intriguingly in opposite with studies in expanding countries. Most of the studies found the teachers focused on native norms and they refused to incorporate ELF into their teaching practices due to the attachment of native speakerism (e.g. Kaur, 2014; Rahayu, 2019; Soruç, 2015; İnceçay \& Akyel, 2014). This study found that the teachers were aware of ELF and its legitimacy in the EFL classroom. This finding might be caused by a variety of exposures that the teachers encountered. For example, some teachers might have studied ELF during their studies. Others might have been involved in ELF communication. Despite different exposures of ELF, the awareness of ELF benefits the teachers in encouraging and revising their teaching practices within the widespread use of English as global lingua franca (Topkaraoğlu \& Dimlan, 2017), developing teachers' professional identity as nonnative English speaker teachers of English (Grazzi \& Lopriore, 2020), allowing teachers to help their students aware of different ways of speaking English (Cogo, 2012) and providing students choices to see themselves as multilingual English speakers, not as inferior nonnative speakers (Galloway \& Rose, 2014). However, it should be highlighted that even though being aware of ELF was considered as a good initial stage for teacher development, actions have to be taken to implement the recognition of the phenomenon of ELF in ELT practice (Topkaraoğlu \& Dimlan, 2017).

Another highlighted point was the teachers expressed positively about native and non-native users of English in the context of EFL in Indonesia. They claimed that teaching English should not only rely on native speakers but also nonnative speakers. They believed that nonnative speakers can contribute to the development of teaching English practice. This point resounds what Jenkins, Cogo, and Dewey (2011) mentioned that nonnative speakers cannot be seen as failed communicators of English yet they are highly skilled communicators of English who utilize their multilingual resources and prioritize successful communication over formal correctness. In a similar vein, nonnative speakers of English may facilitate mutual intelligibility (Deterding \& Kirkpatrick, 2006).

Further, the present study also demonstrated that the teachers believed that standard norms of English were a necessity in teaching objectives yet they realized that communicative effectiveness was prominently important rather than formal correctness. This finding was similar to Luo's (2016) study who found out that teachers in Taiwan emphasized the necessity of native-speaker norms in teaching English even though they recognized the importance of raising students' awareness of ELF. It is also 
supported by Rahayu (2019) who found out teachers perceived Standard English as the most suitable in English classrooms.

Furthermore, the teachers perceived the ultimate goal of learning EFL was not becoming nativelike English users yet becoming efficient communicators in international and multilingual communication beyond language diversity and cultures. This finding indicated that the teachers recognized the irrelevance of teaching a standard variety of English in teaching English as a foreign language. To exemplify, in teaching pronunciation, learners should not be expected to accurately produce British English or American English pronunciation but be encouraged to preserve their accents (Nagy, 2016). Since the teachers believed that being efficient communicators was much more important than nativeness, it is implied that the teachers acknowledged the need for communication strategies in the context of ELF interaction. Communication strategies can accommodate communication and avoid confusion (Mauranen, 2006). The communication strategies or accommodating strategies covered placing a question into the subject line, self-regulation, codeswitching, repetition, paraphrasing, clarification, self-repair, the avoidance of localized vocabulary and idioms, and 'let it pass' strategy (Cogo, 2009; Kaur, 2009; Kirkpatrick, 2008; Nagy, 2016).

The last finding demonstrated the teachers positively assimilated the incorporation of ELF into their teaching practice. It is found that the teachers believed students should be aware of English varieties and learn them in the classroom. They were also aware that ELF awareness was very important and necessary to be learned by students in the classroom. This finding showed that the teachers' tendency to stick to native speakerism is gradually changing to a more open-minded approach to language variability (Grazzi \& Lopriore, 2020). As a result, reflection needs to be prepared within English language teacher education programs to move beyond native/nonnative distinction, to accept non-native English, and to widen the borders of language awareness (Lopriore, 2018).

\section{Some challenges in incorporating ELF into English teaching}

To begin with, this present study portrayed some benefits of ELF awareness in teaching and learning English. Those benefits include helping students to increase their confidence, motivating students in learning English, promoting intercultural communication, and expanding better job opportunities. Despite all benefits, the teachers claimed several challenges that might be encountered when they incorporate ELF instruction into their teaching practice. Firstly, the teachers agreed that unfamiliarity with other accents was a major possible problem. Secondly, they mentioned that teachers, students, and institutions should be cooperatively ready when they attempt to incorporate ELF instruction in the classroom. Further, providing suitable materials was also mentioned by the participants as a prospective challenge. Last, native speakerism was also mentioned as a challenge. Therefore, all challenges mentioned previously are presented in the discussion below.

This study revealed that the teachers agreed that unfamiliarity with other accents was a major possible problem. The teachers stated they often encountered difficulties even when they taught British English and American English. Hence, the teachers believed that teaching other accents was exceptionally demanding. It is supported by Shibata (2009) and Shim (2002) who argued that teachers, especially in Asian contexts, appeared to be more attached to western culture and the American English variety. In a similar vein, Kaur (2014) accentuated that British and American accents were seen as superior and standard compared to nonnative English accents.

Another finding showed that there was a need for readiness for teachers, students, and institutions when they attempted to incorporate ELF instruction in the classroom. This finding was in accord with Sifakis (2004) and Young and Walsh (2010) who clarified that to incorporate ELF instructions (or 
teach ELF-related skills), teachers require understanding not only knowledge of English but also an understanding of local context and related cultures. Furthermore, teachers' knowledge about the nature of ELF was also significant. If the teachers had a limited understanding of ELF, they might have been eminently reluctant to teach it (Young \& Walsh, 2010). Regarding institutions, Sifakis (2009) highlighted that schools should prepare learners for realistic situations. To exemplify, the school can invite nonnative English speakers as teacher guests so that students can involve in communication with nonnative speakers.

It was worth pointing out that providing suitable materials was also a prospective challenge. The lack of teaching materials potentially drove teachers hesitant to expose ELF instruction even though they have already been aware of ELF (Luo, 2016; Nagy, 2016). Hence, it would also be a concern for teachers who attempted to incorporate ELF in their own teaching context to engage with growing ELF literature and develop learning materials and pedagogical practice (Sifakis, 2014). Dealing with this issue, Sifakis (2009) proposed an ELF teacher education program that emphasizes the ability of teachers to use technology to make links with nonnative speakers from other countries and help to raise teacher awareness of the communication value of ELF.

Furthermore, native speakerism was also mentioned as a predicted challenge. It is evident that expanding circle countries such as Indonesia, where English is taught as EFL, are dependent on innercircle norms or exonormative norms (McKay, 2003). Studies revealed that being oriented to native speakerism has been a prominent feature of teaching English in expanding circle countries (Evans, 2010; Kang, 2015; Monfared \& Khatib, 2018; Saengboon, 2015; Snodin \& Young, 2015). There are three reasons why expanding circle countries favored native speakerism (Kirkpatrick, 2007). First, native speaker models have prestige and legitimacy (Kirkpatrick, 2007). To exemplify, grammar and dictionaries were available and codification led to the acceptance of a standard. Secondly, language teaching materials were based on native speakers were effortlessly available (Kirkpatrick, 2007). Last, the Ministry of Education was keen to provide the best standards and facilitate students with an internationally recognized and internationally intelligible variety of English (Kirkpatrick, 2007). Responding to the issue of native speakerism, this study indicated that there is a need of preparing teachers to deal with native speakerism which is highly attached to teaching English in Indonesia.

\section{CONCLUSIONS}

The present study aims at investigating EFL teachers' attitudes towards teaching and learning English as a lingua franca and possible challenges that might be encountered by teachers regarding incorporating ELF into their teaching practice. Firstly, this study revealed that teachers have been aware of ELF and its legitimacy in the EFL context. This finding is interesting since many studies show that teachers in expanding circle countries are attached to native speakerism in their teaching practice. Additionally, they also viewed native speakers and nonnative speakers contributed to teaching English. Further, they acknowledged the necessity of standard norms yet they recognized the importance of communicative effectiveness over formal correctness. In a similar vein, they believed that EFL learning does not merely aim at achieving nativeness but becoming efficient communicators in international and multilingual communication beyond language diversity and cultures. In conclusion, the teachers had a positive attitude towards teaching and learning ELF in the Indonesian EFL context.

It should be noted that the teachers highlighted several challenges that they needed to deal with in regards to incorporating ELF into their teaching practice. The teachers mentioned unfamiliarity with other accents could possibly trouble them and their students. They were also concerned about the readiness of teachers, students, and institutions in incorporating ELF instruction. Moreover, they accentuated providing suitable learning materials as a daunting task because the materials were not as 
available as exonormative norm materials. Last, they expressed the attachment of teaching English in Indonesia with native speakerism as their huge challenge.

There are several suggestions offered for policymakers and future researchers. For policymakers, teachers' awareness of ELF signaled the need for teacher training. The training can facilitate teachers to raise their awareness of ELF, foster their knowledge about ELF, and help them deal with challenges of incorporating ELF in teaching practice such as providing suitable learning materials. The training can also prepare teachers to cope with the ELF era effectively. For future researchers, it is suggested to explore students' attitudes toward ELF since this present study only focused on teachers' attitudes. Additionally, since the number of participants in this study was limited, conducting studies with a wider scale and range would be beneficial to represent Indonesian EFL teachers' voice of teaching and learning English as a lingua franca.

\section{REFERENCES}

Asakereh, A., Yousofi, N., \& Weisi, H. (2019). ELF in the Iranian education system: Exploring teacher trainers' and pre-service/in-service English teachers' attitudes. Cogent Education, 1-32.

Bayyurt, Y., \& Sifakis, N. (2015). Developing an English as a lingua franca pedagogy; Insights from self-education program. In P. Vettorel, New frontiers in teaching and learning English (pp. 5576). Newcastle Upon Tyne: Cambrige Scholar Publishing.

Bjørge, A. (2012). Expressing disagreement in ELF business negotiations: Theory and practice. Applied Linguistics, 33(4), 406-427.

Brown, J. D. (2012). EIL curriculum development. In L. Alsagoff, S. McKay, G. S. Hu, \& W. A. Renandya, Principles and practices for teaching English as an international (pp. 147-167). New York: Routledge.

Cogo, A. (2009). Accommodating difference in ELF conversations: A study of pragmatic strategies. In A. Mauranen, \& E. Ranta, English as a lingua franca: Studies and findings (pp. 254-273). Newcastle upon Tyne: Cambridge Scholars Publishing.

Cogo, A. (2012). English as a lingua franca: Concepts, use and implications. ELT Journal, 97-105.

Coskun, A. (2010). Whose English should we teach? Reflections from Turkey. ESP World, 9(1), 1-20.

Crystal, D. (2003). English as a global language. Cambridge: Cambridge University Press.

Decke-Cornill, H. (2002). 'We would have to invent the language we are supposed to teach': The issue of English as Lingua Franca in language education in Germany. Language, Culture and Curriculum, 15(3), 251-263.

Deterding, D., \& Kirkpatrick, A. (2006). Emerging South-East Asian Englishes and intelligibility. World Englishes, 25(3/4), 391-409.

Evans, B. E. (2010). Chinese perceptions of Inner Circle varieties of English. World Englishes, 29(2), 270-280.

Fang, F. G. (2017). English as lingua franca: Implication for pedagogy and assessment. TEFLIN Journal, 57-70.

Firth, A. (1996). The discursive accomplishment of normality: On conversation analysis and lingua franca English. Journal of Pragmatics, 26, 237-259.

Floris, F. D. (2014). Idea sharing: Introducing English as an International Language (EIL) to preservice teachers in a World Englishes course. PASAA, 47, 215-231.

Galloway, N., \& Rose, H. (2014). Using listening journals to raise awareness of Global Englishes in ELT. ELT Journal Advance Access, 1-11.

Grazzi, E., \& Lopriore, L. (2020). ELF awareness for teacher education in Italy: Attitudes and actions. Estudos Linguisticos e literarios, 69-89. 
İnceçay, G., \& Akyel, A. (2014). Turkish EFL teachers' perceptions of English as a Lingua Franca. Turkish Online Journal of Qualitative Inquiry, 5(1), 1-12.

Jenkins, J. (2009). English as a lingua franca: Interpretations and attitudes. World Englishes, 28(2), 200-207.

Jenkins, J., Cogo, A., \& Dewey, M. (2011). Review of developments in research into English as a lingua franca. Lang. Teach., 44(3), 281-315.

Kang, O. (2015). Learners' perceptions toward pronunciation instruction in three circles of World Englishes. TESOL Journal, 6(1), 59-80.

Kaur, J. (2009). Pre-empting problems of understanding in English as a lingua franca. In A. Mauranen, \& E. Ranta, English as a Lingua Franca: Studies and Findings (pp. 107-123). Newcastle upon Tyne : Cambridge Scholars Publishing.

Kaur, J. (2010). Achieving mutual understanding in World Englishes. World Englishes, 29(2), 192-208. Kaur, J. (2014). Attitudes towards English as a Lingua Franca. Procedia Social and Behaviour Science, 214-221.

Kirkpatrick, A. (2007). World Englishes implications for international communication and English language teaching. Cambridge: Cambridge University Press.

Kirkpatrick, A. (2008). English as the official working langiage of the Association of Southeast Asian Nations (ASEAN): Features and strategies. English Today, 24(2), 27-24.

Kirkpatrick, A., \& Sussex, R. (2012). English as an International Language in Asia: Implications for Language Education. New York: Springer.

Lopriore, L. (2018). ELF in ELT education: New paradigms in language awareness. In: ELF-awareness in ELT: Bringing together theory and practice. Journal of English as a Lingua Franca, 7(1), $160-166$.

Luo, W. (2016). Teacher perceptions of teaching and learning English as a lingua franca in the expanding circle: A study of Taiwan. English Today, 1-10.

Mairi, S. (2016). an English as a Lingua Franca (EFL) perspektif in asian English language taaching (ELT). Proceedings of the Fourth International Seminar onEnglish Language and Teaching (ISELT-4), 283-293.

Matsuda, A. (2003). Incorporating World Englishes in teaching English as an International Language. TESOL Quarterly, 37(4), 719-729.

Matsuda, A., \& Friedrich, P. (2011). 'English as an international language: A curriculum blueprint. World Englishes, 30(3), 332-344.

Mauranen, A. (2006). Signaling and preventing misunderstanding in English international. Journal of the Sociology of Language, 177, 123-150.

Mauranen, A. (2018). Conceptualising ELF. In J. Jenkins, W. Baker, \& M. Dewey, The Routledge Handbook of English as a Lingua Franca (pp. 7-24). New York: Routledge.

McKay, S. L. (2003). Toward an appropriate EIL pedagogy: Re-examining common ELT assumptions. International Journal of Applied Linguistics, 13(2), 1-22.

McKay, S. L. (2012). Principles of teaching English as an International Language. In L. Alsagoff, S. L. McKay, G. S. Hu, \& W. Renandya, Principles and Practices for Teaching English (pp. 28-46). New York: Routledge.

Monfared, A., \& Khatib, M. (2018). English or Englishes? Outer or Expanding Circle Teachers' Awareness of and Attitude toward Their Own Variants of English in ESL/EFL Teaching Context. Australian Journal of Teacher Education, 43(2), 56-75.

Mukminatien, N. (2012). Accommodating World Englishes on developing EFL learners' oral communication. TEFLIN Journal, 23, 222-232. 
Musthafa, B., Hamied, F. A., \& Zein, S. (2019). Enhancing the quality of Indonesian teachers in the ELF era. In S. Zein, Teacher education for English as a Lingua Franca: Perspectives from Indonesia (pp. 175-190). New York: Routledge.

Nagy, T. (2016). English as a Lingua Franca and its implications for teaching English as a foreign language. Acta Universitas Sapientiae, Philologica, 8(2), 155-166.

Rahayu, G. (2019). Indonesian EFL teacher' perception about teaching English as a lingua franca. LangEdu Journal, 1-14.

Saengboon, S. (2015). An exploratory study of Thai university students' understanding of World Englihes. English Language Teaching, 8(11), 131-154.

Seidlhofer, B. (2005). English as a lingua franca. ELT Journal, 59(4), 339-341.

Seidlhofer, B. (2009). Common ground and different realities: World Englishes and English as a lingua franca. World Englishes, 28(2), 236-245.

Seidlhofer, B. (2011). Understanding English as a lingua franca. Oxford: Oxford University Press.

Shibata, M. (2009). Japanese pre-service teachers' attitudes towards AETs. JALT, 984-997.

Shim, R. (2002). Changing attitudes towards teaching English as a world language in Korea. Journal of Asian Pasific Communication, 12(1), 143-158.

Sifakis, N. (2004). Teaching EIL - teaching international or intercultural English: what teacher should know. System, 32(2), 237-250.

Sifakis, N. (2009). Challenges in teaching ELF in the perphery: The Greek context. ELT Journal, 63(3), 230-237.

Sifakis, N. (2014). ELF awareness as an opportunity for change: A transformative perspective for ESOL teacher education. Journal of English as a Lingua Franca, 3(2), 317-335.

Snodin, N., \& Young, T. (2015). 'Native-speaker' varieties of English: Thai perceptions and attitudes. Asian Englishes, 17(3), 248-260.

Soruç, A. (2015). Non-native teachers' attitudes towards English as a Lingua Franca. Hacettepe Üniversitesi Eğitim Fakültesi Dergisi (H. U. Journal of Education), 30(1), 239-251.

Topkaraoğlu, M., \& Dimlan, H. (2017). ELF awareness in English language education. International Journal of Language Academy, 5(5), 39-58.

Young, T., \& Walsh, S. (2010). Which English? Whose English? An investigation of 'non-native' teachers' beliefs about target varieties. Language, Culture and Curriculum, 1-15.

Yücedağ, Z., \& Karakaş, A. (2019). High school language division stuidents' perceptions of English as a Lingua Franca. Proceedings of the Fourth International Seminar on English Language and Teaching (ISELT-4), 27-42. 